\title{
Microbiome management in the social amoeba Dictyostelium discoideum compared to humans
}

\author{
TIMOTHY FARINHOLT' ${ }^{1}$, CHRISTOPHER DINH ${ }^{1,2}$ and ADAM KUSPA*,1,2 \\ ${ }^{1}$ Verna and Marrs McLean Department of Biochemistry and Molecular Biology and \\ ${ }^{2}$ Department of Molecular and Human Genetics, Baylor College of Medicine, Houston TX, USA
}

\begin{abstract}
Social amoebae and humans use common strategies to orchestrate their interactions with the bacteria in their respective environments and within their bodies. These strategies include the elimination of bacteria by phagocytosis, the establishment of mutualistic interactions, the elaboration of physical barriers, and the deployment of innate immune cells. Many of the molecular mechanisms that humans and social amoebae employ differ, but there are striking similarities that may inform studies in each organism. In this topical review we highlight the similarities and consider what we might learn by comparing these highly divergent species. We focus on recent work in Dictyostelium discoideum with hopes of stimulating work in this area and with the expectation that new mechanistic details uncovered in social amoebae-bacteria interactions will inform microbiome management in humans.
\end{abstract}

KEY WORDS: lectin, endosymbiosis, extracellular traps, bacteria

\section{Introduction}

The interactions between host eukaryotes and their bacterial associates are regulated by host effectors that recognize bacteria and facilitate their destruction or maintenance. These effectors are found across extant eukaryotes, but prior to the advent of metazoa complex interaction setween amoebae and bacteria were shaped by at least a billion years of evolution in shared environments. Today, it is well established that complex communities of bacteria with interconnected metabolisms significantly influence the physiology of their eukaryotic hosts. An increasing recognition of the importance of the microbiome in human development, health, and well being, drives the study of host effectors that control its bacterial composition (Peterson and Artis 2014, Singh et al., 2017, Dominguez-Bello et al., 2019). Social amoebae like Dictyostelium discoideum recognize specific bacterial species and respond in specific ways to effect advantageous interactions when feeding on them and during their multicellular phase. Likewise, bacteria have acquired diverse means to optimize their survival in the soil and avoid deleterious interactions with amoebae. The bacterial diversity faced by $D$. discoideum in the soil is similar in important ways to the challenges that humans face in maintaining a healthy microbiome. In the soil there are bacterial species that are highly pathogenic to amoebae and those that are less so that can serve as a food source for $D$. discoideum. Examining amoebae-bacteria interactions in an experimentally tractable model organism like $D$. discoideum provides an opportunity to identify novel mechanisms mediating host-microbe interactions that may inform microbiome regulation in humans.

The social amoeba $D$. discoideum lives in the forest soil predating on bacteria and once food is depleted they begin a highly coordinated developmental process consisting of transcriptional and morphological changes (Fig. 1; Kessin 2001, Rosengarten et al., 2015). Amoebae prey on bacteria and divide mitotically and their exposure to different bacterial species results in specific transcriptional responses that serve to optimize survival (Nasser et al., 2013). Amoebae use phagocytosis to manage bacterial populations during growth, a cellular process that has a common heritage across eukaryotic phylogeny, though humans no longer rely on the process for nutrients (Boulais et al., 2010). Once starved, cells commit to development and lose their phagocytic capacity (Katoh et al., 2007, Roberge-White et al., 2011). Amoebae aggregate and follow a stereotypic morphogenesis to produce a fruiting body consisting of a sorus of reproductive spores held aloft by dead cellular stalk (Kessin, 2001). The amoebae are vulnerable to infection by pathogens during development, especially during the motile slug stage that can last for days and where slugs may traverse bacteria-rich locales. However, $D$. discoideum has innate

Abbreviationsused in this paper: LIMBI, lectin-induced modified bacterial internalization.

*Address correspondence to: Adam Kuspa. Verna and Marrs McLean Department of Biochemistry and Molecular Biology, Baylor College of Medicine, Houston TX 77030, USA. E-mail: akuspa@ bcm.edu - (D) https://orcid.org/0000-0002-9156-148X

Submitted: 20 June, 2019; Accepted: 18 July, 2019.

ISSN: Online 1696-3547, Print 0214-6282

(0) 2019 UPV/EHU Press (Bilbao, Spain) and Creative Commons CC-BY. This is an open access article distributed under the terms of the Creative Commons Attribution License (http://creativecommons.org/licenses/), which permits you to Share (copy and redistribute the material in any medium or format) and Adapt (remix, transform, and build upon the material for any purpose, even

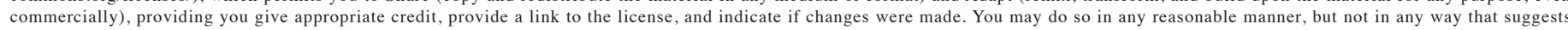
the licensor endorses you or your use. Printed in Spain 


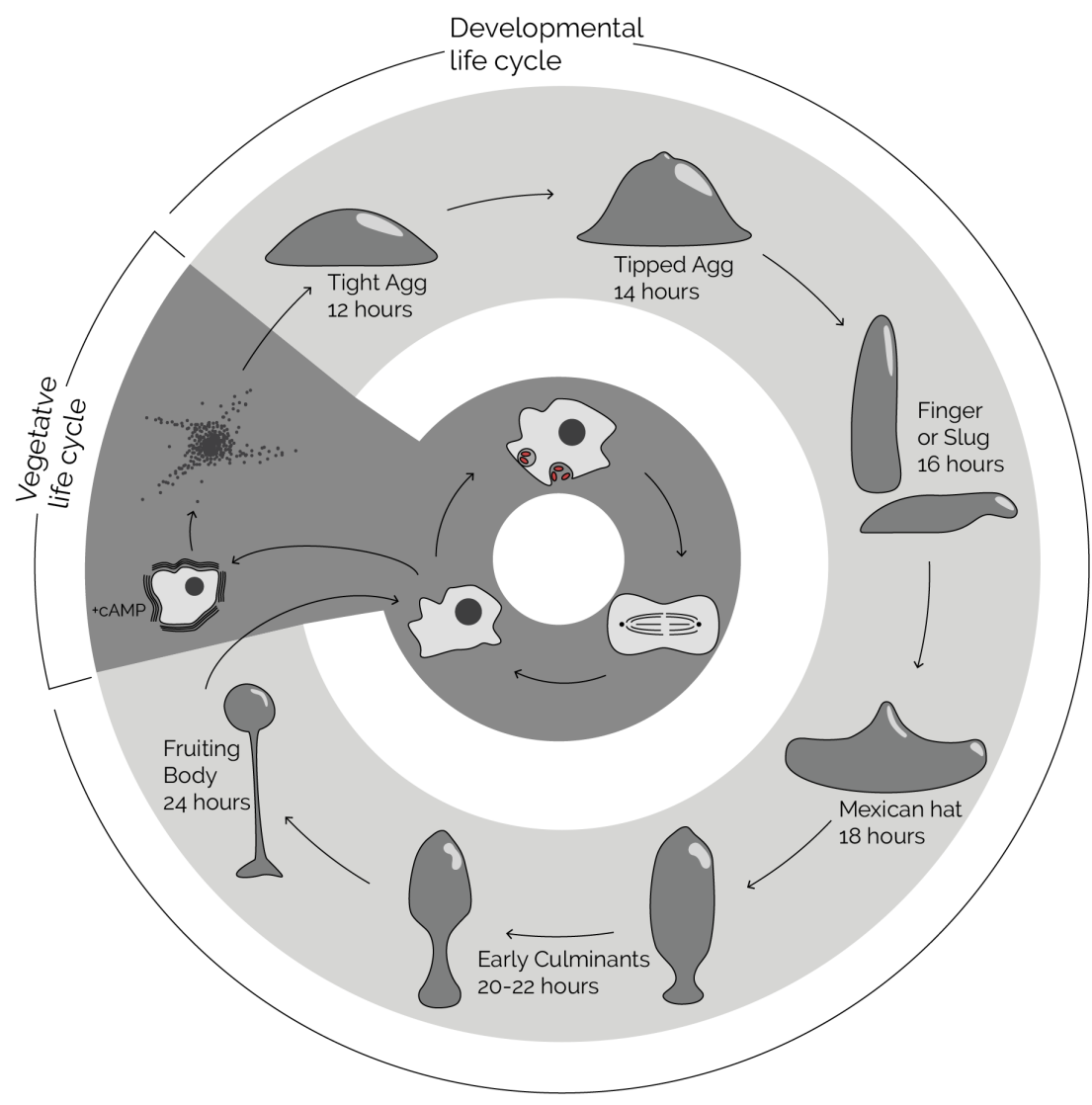

Fig. 1. Dictyostelium discoideum life cycle. Amoebae predate on bacteria and divide mitotically (inner circle). Once a cell begins to starve, it emits a pulse of CAMP that propagates through surrounding cells beginning development. Amoebae then aggregate, undergo cellular differentiation, and pass through distinct morphogenetic stages to reach the fruiting body consisting of a sorus of reproductive spores held aloft by dead stalk cells (from Farinholt 2019).

immune system comprised of Sentinel cells that make up $1 \%$ of the slug cells population and which function like human neutrophils in that they respond to invading pathogens and clear them from the slug 'body' by phagocytosis and through the elaboration of DNA-based extracellular traps (ETs) that kill bacteria (Chen et al., 2007, Zhang et al., 2016).

Even with the evolutionary distance separating amoebae and humans ( $\sim 1$ billion years) and the radically differing lifecycles, specific similarities persist in their interactions with bacteria (Eichinger etal., 2005). For example, intracellular bacterial pathogens infect $D$. discoideum and humans in ways that share significant mechanistic details. Legionella pneumophila infects $D$. discoideum amoebae and human macrophages using the same type-IV secretion system and $D$. discoideum has provided a simple model to study the persistence of $L$. pneumophila within the phagolysosome and to develop potential new therapies (Hagele 2000, Cosson and Soldati 2008, Clarke 2010, Bozzaro and Eichinger 2011, Harrison et al., 2015). Similarities between human and amoebal interactions with bacteria have led some to hypothesize that the selection imposed on bacteria by amoebal predation caused bacteria to develop mechanisms that are useful for escaping the human immune system (Molmeret et al., 2005, Casadevall and Pirofski 2007, Adiba 2010). Amoebae are also potential environmental reservoirs for known pathogens such as Yersinia pestis (Casadevall and Pirofski 2007, Markman et al., 2018). This suggests that understanding effectors that govern interactions between amoeba and bacteria will provide insight into human immune effectors and identifying amoebaresistant bacteria might uncover new potential human pathogens (Greub and Raoult 2004).

In this review we consider three aspects of microbiome management in $D$. discoideum; as the amoebae grow in plaques on bacterial lawns, how they maintain bacteria during multicellular development, and their use of DNA-based extracellular bacterial traps. In each of these cases, lectins are critical determinants of amoebal microbiome management with implications for human microbiome management. Described below are analyses of four families of protein lectins secreted from $D$. discoideum amoebae exposed to K. pneumoniae food bacteria, with functional information for two of them in microbiome management: the cadherin-related proteins $\mathrm{CadA}, \mathrm{Cad} 2$ and Cad3; the H-type discoidin I lectins Discoidin-IA (DscA), and Discoidin-IC (DscC); the concancavalin A lectin related IliE proteins, IliE-1 and IliE-2; and the Ricin $B$ lectin related Cup proteins, CupA-J (Eichinger et al., 2005). Our goal is to compare amoebae with humans so we now briefly review the use of lectins in mammalian microbiome management.

\section{Microbiome management in the mammalian gut}

The maintenance of mammalian microbiomes involve the opposing processes of inclusion and exclusion of specific bacterial species within specialized niches with natural selection favoring the outcome of retaining beneficial commensals while eliminating pathogens (Ley et al., 2008). Compositional control of the microbiome is often studied in the mammalian small intestine where resident adaptive and innate immune cells within the epithelium of the mammalian small intestine control lumenal bacteria with a variety of effectors (Peterson and Artis 2014, Langdon et al., 2016, Singh et al., 2017). Stem cells reside at the bottom of the villi, in the crypts, where they differentiate into nutrient absorbing epithelial cells and specialized innate immune Goblet and Paneth cells. These cells secrete proteins into intestinal crypts, preventing infiltration of bacteria through antibacterial, spatial-restricting, or agglutinating activities.

The main mechanism for preventing bacterial access to the host gut epithelium is through the formation of a physical barrier (Peterson and Artis 2014). This barrier is comprised of proteins and small molecules that act together to prevent access to the host and limit the toxicity and infectivity of bacteria. This barrier is known to be essential because some gut-resident microbes are beneficial commensals when stably sequestered in this gut barrier, but are pathogenic if allowed to enter the epithelium (Sina et al., 2017). Mucin proteins form the mucus lining of the gut and are critical for barrier formation. Goblet cells secrete soluble mucins and membrane associated mucins that interact to form the gel-like mucus that provides a $\sim 50-\mu \mathrm{m}$ physical barrier between the epithelium 
A

Fig. 2. Host-bacteria separation by lectin-based barriers. (A) The mouse gut maintains a 50-um barrier between luminal bacteria and the host using mucus, lectins and antimicrobials (Corfield 2018). When these systems are perturbed as in a Myd88- mutant mouse, the lectin Regllly is not produced and the barrier breaks down (Vaishnava et al., 2011). (B) Amoebae maintain separation at the growing edge using CadA as a lectin that agglutinates the food bacteria. When this is knocked out in cadAmutant amoebae the bacteria and amoeba mix as illustrated in the upper right-hand panel (Farinholt et al., 2019).

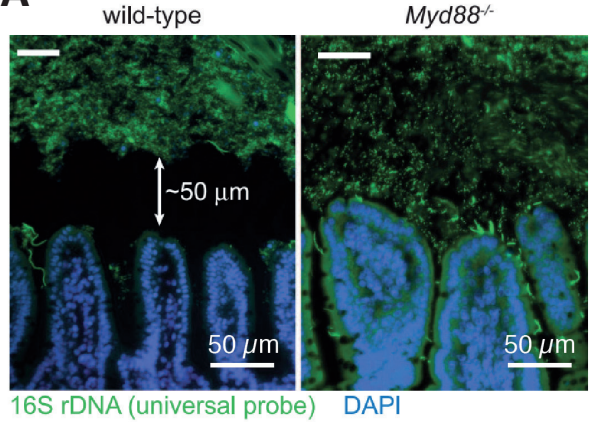

16S rDNA (universal probe) DAPI

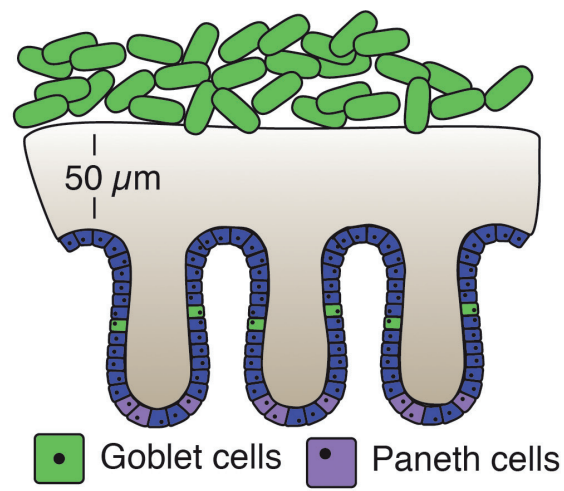

B

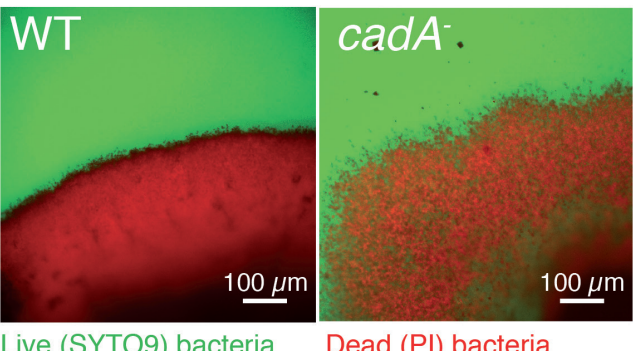

Live (SYTO9) bacteria and the microbiome (Corfield 2013, McCauley and Guasch 2015, Corfield, 2018). Current models suggest that mucus forms from highly crosslinked mucins that produce net-like structures that are stratified into a dense tightly epithelium-associated lower layer and a less dense, more fluid upper layer (Ambort et al., 2012, Johansson et al., 2008). The general utility of mucus in microbiome control has not been thoroughly explored and the evolution of mucin homologs is not well understood, but mucin related proteins have been identified in frogs (Xenopus), ghost sharks, chickens, comb jellies (Cnidaria, Proifera, and Ctenophora), and D. discoideum (Lang et al., 2016). The $D$. discoideum cotE gene produces a spore coat protein that contains mucin-like repeats, but it is not known if it functions in other contexts as a mucin. Nonetheless, the phylogenetic distribution suggests that mucin-like proteins arose prior to the advent of metazoan species so it is possible that mucins are utilized by non-metazoan eukaryotes to provide separation from environmental microbes.

The Paneth cells found in the bottom of intestinal crypts secrete proteins that spatially separate bacteria from host and they also contain specialized secretory granules filled with antimicrobials (Ouellete2010, Porter et al., 2002). One granule-associated protein in the mouse, Reglll $\gamma$, is part of the Reg (regenerating gene family protein III) gene family and the human homolog HIP/PAP and is a C-type lectin (Cash et al., 2006). C-type lectins are a superfamily of $\mathrm{Ca}^{2+}$-dependent carbohydrate-binding proteins that participate in many physiological functions including immunity (Zelensky and Gready 2005, Brown et al., 2018, Mayer et al., 2017). In mice, Regllly binds the peptidoglycan of Gram(+) bacteria and has no measureable affinity for the surface carbohydrates of Gram(-) bacteria (Cash et al., 2006). Consistent with this, Regllly has antibacterial activity towards Gram(+) bacteria and low activity towards Gram(-) bacteria (Cash et al., 2006, Miki et al., 2012, Mukherjee et al., 2014). The ability of Regllly to selectively target Gram(+) bacteria is an example of protein specificity leveraged to control specific resident microbes. The $\sim 50-\mu \mathrm{m}$ barrier of the intestinal epithelium is absent in Reglll $\gamma^{/-}$mice, underscoring the importance of this lectin in barrier immunity (Fig. 2A, Vaishnava et al., 2011). Other members of the Reg gene family expand this control as exemplified by mouse Reglll $\beta$ that kills both $\operatorname{Gram}(-)$ and $\operatorname{Gram}(+)$ bacteria (Miki et al., 2012, Stetler et al., 2011). The expression of Reglll $\gamma$ and Reglll $\beta$ is stimulated by symbiotic bacteria through Toll-like receptor (TLR) signaling, suggesting that C-type lectins have evolved as mediators of innate immunity (Cash et al., 2006).

Human defensins represent another peptide family required for spatial separation between host and microbiome through direct antimicrobial activity and spatial restriction. Defensins are small $(<5$ kDa) cationic peptides with activity against $\operatorname{Gram}(+)$ and $\operatorname{Gram}(-)$ bacteria, fungi, and viruses. Human a-defensin HD5, a 32-residue peptide secreted by Paneth cells, has bactericidal activity against Gram(+) and Gram(-) bacteria (Nakamura et al., 2016). HD5 agglutinates bacteria and induces cellular elongation and blebbing of bacterial cells leading to death (Chileveru et al., 2015). Interestingly, the mouse homolog of HD5, cryptdin-4, shows relatively low bactericidal activity towards commensals while efficiently clearing pathogenic species from the gut (Nakamura et al., 2016). Mice deficient in the defensing-maturation metalloprotease MMP7 have altered microbiome compositions, increased infection risk, and bacteria have direct access their gut epithelia (Salzman et al., 2010). Although similar in sequence and structure to HD5, human a-defensin HD6 is secreted by Paneth cell in the gut for a distinctly different function (Szyk et al., 2006, Masuda et al., 2011). Unlike HD5, HD6 demonstrates little bactericidal activity for any bacterial species that have been tested (Ericksen et al., 2005). Instead, HD6 agglutinates bacteria and protects mice from translocation of Salmonella typhimurium to lymph nodes (Chu et al., 2012). Since HD5 and HD6 are likely products of a gene duplication event, it 
is interesting that HD6 maintained its agglutinating activity over time while its bactericidal activity was lost.

The key strategy that mammals use in establishing a barrier in the gut that separates bacteria from host cells allows them to manage their microbiome at a distance by secreting effectors into the barrier; anti-bacterial proteins and peptides, and lectins. The importance of a properly functioning mucus barrier is evident in inflammatory bowel diseases (IBD) such as Crohn's disease (CD) (Strugala et al., 2008, Sina et al., 2018). A hallmark of IBD is epithelial associated bacteria where dysregulated antimicrobial and agglutinating proteins compromise the spatial separation (Vaishnava et al., 2011, Wehkamp and Stange 2010, Gassler 2017, Nishida et al., 2018). Tissue samples from patients with CD, or ulcerative colitis (UC), present with bacteria adhering to the gut mucosa, indicating a failure of the normal barrier, leading to widespread inflammation (Swidsinski et al., 2005). Thus mammals normally fine-tune their microbiome by either killing pathogenic bacteria or retaining commensal bacteria, all while keeping the bacteria a safe distance from the epithelial surface.

\section{Microbiome management by social amoebae during vegetative growth}

It is not obvious that unicellular amoebae manage bacterial populations during vegetative growth in the traditional sense of establishing and maintaining a microbiome. However, amoebae grow in colonies and when the bacterial food supply is plentiful they form plaques - uniform circles of feeding amoebae on lawns of food bacteria on agar plates in the laboratory, and (one imagines) varied plaque geometries on three-dimensional collections of bacterial food in the wild. Additionally, recent evidence suggests that $D$. discoideum amoebae grow in cooperative groups, suggesting the intercellular communication does occur during the growth (Rubin et al., 2019). Amoebae also maintain intricate transcriptional differences when growing on different food bacteria so this may represent, in part, a response in the environmental bacteria (Nasser et al., 2013). Several recent studies implicate the lectins discoidin IA (DscA), discoidin IC (DscC), and the cadherinrelated adhesion protein DdCAD-1 (CadA) in the control of the $D$. discoideum bacterial interactions during vegetative growth (Dinh et al., 2018, Farinholt et al., 2019). As outlined below, these studies suggest that the amoebal plaque in fact operates as a tissue of cells managing a microbiome on the outside where environmental bacteria are held at bay so that the amoebae have access to food without risking exposure to bacterial toxins or potential pathogens.

The previously unknown vegetative function of $\mathrm{CadA}$ in bacterial control was suggested by transcriptomic and proteomic analyses of amoebae-bacteria interactions (Nasser et al., 2013, Dinh et al., 2018), but it was first characterized in studies of amoebal cell-cell adhesion during development (Wong et al., 2002). CadA is a 24$\mathrm{kDa}$ protein that adopts a two-domain secondary structure, both folding into Greek key motifs common in immunoglobulins (Lin et al., 2006). The n-terminal domain is a member of the $\beta \gamma$-crystallin family with three $\mathrm{Ca}^{2+}$ binding sites and it is connected to the cterminal cadherin-related domain by a short linker. Synthesized as a soluble protein, the c-terminal domain of CadA anchors the protein to the membrane and homotypic binding is achieved through $\mathrm{N}$-to-N terminal domain binding that requires $\mathrm{Ca}^{2+}$ (Lin et al., 2006). Without a signal sequence or transmembrane domain, CadAlocal- izes to the contractile vacuole membrane and is exported through a non-canonical process (Sesaki et al., 1997). Prior to export, CadA binds calmodulin on the cytosolic membrane of the contractile vacuole in a calcium dependent manner (Sriskanthadevan et al., 2009, Sriskanthadevan et al., 2013). Time-lapse microscopy of amoebae expressing CadA-GFP showed vesicular structures in the lumen of the contractile vacuole suggesting export occurs through invagination of the contractile vacuole membrane and secretion of the resulting CadA-containing vesicles. Cells in the multicellular slug of $D$. discoideum are organized into tissues that will give rise to the terminally differentiated cell types. Prespore cells reside in the posterior 80 percent of the slug while prestalk cells make up the anterior 20 percent. Mutant $c a d A^{-}$slugs displayed cell-type proportioning and cell sorting defects, with a 2.5-fold increase in prestalk cells, and fruiting body morphogenesis was delayed by 6 hours (Wong et al., 2002, Sriskanthadevan et al., 2011). The relatively subtle developmental defects observed in cadA knockout mutants may be due to its function being compensated for by expression of the highly related Cad3 protein.

The potential of a vegetative function for CadA was revealed when the $\operatorname{cad} A$ gene was found to be induced in $D$. discoideum growing on K. pneumoniae and other Gram(-) bacteria (Nasser et al., 2013) and when it was identified by mass spectrometry as being specifically secreted during growth (Dinh et al., 2018). Plating cadA- amoebae on K. pneumoniae or $E$. coli results in decreased viability compared to wild-type amoebae, while with species of Gram(+) bacteria (B. subtilis, M. luteus, S. aureus) cadA-amoebae are as viable as wild type amoebae. These data imply that CadA is necessary for growth on thick lawns of Enterobacteriaciae. This viability defect is not observed at low bacterial densities, or when exogenously purified $\mathrm{Cad} A$ is supplied to the mutants growing on high-density bacteria, indicating that the essential function of $\mathrm{Cad} A$ during growth on high-density bacteria is carried out extracellularly (Farinholt et al., 2019). It is plausible that high-density bacteria present an environment that is more challenging to amoebal survival, especially individual amoebae attempting to form a clonal plaque, which is what the viability assay assesses. The ability to observe cad $A^{-}$mutant amoebae form plaques on low-density bacterial lawns revealed the essential function of CadA. Plaques formed by $\operatorname{cad} A^{-}$amoebae on low-density bacterial lawns are irregularly shaped with diffuse edges and satellite colonies, whereas wild-type amoebae always produce sharp-edged plaques. It turns out that this plaque morphology is the result of reciprocal intercalation of the two species across the plaque border, with amoebae travelling outward into the bacterial lawn and live bacteria persisting within the plaque itself (Fig. 2B, Farinholt et al., 2019). Wild-type plaques have distinct borders with live bacteria present solely outside of the growing edge (Dinh, etal., 2018). These observations suggest that CadA functions to maintain a robust plaque border that excludes live bacteria from intermingling with the amoebae.

A clue to CadA's function came when it was discovered to have lectin activity and to bind to bacteria (Farinholt et al., 2019). CadA protein binds to a broad spectrum of bacterial species, but it induces agglutination only of $K$. pneumoniae and $E$. coli, two species of Enterobacteriaciae, but not other bacteria that were tested (Farinholt et al., 2019). The fact that CadA binds bacteria is not completely unexpected since another cadherin-related protein, RapA2 from Rhizobium, binds acidic bacterial exopolysaccharides on the surface of the cells that produce it (Abdian et al., 2013). RapA2 
has two highly similar cadherin-like domains and if both domains have lectin activity it would explain how it causes agglutination and biofilm formation. CadA has one cadherin domain on its c-terminus that likely contains the carbohydrate binding activity and it forms homodimers through the interaction of its n-terminal domains, a structure that would allow it bind to two bacterial cells (Lin et al., 2006). An indication of CadA's function in vivo comes from its ability to spatially restrict the growth of $K$. pneumoniae and E. coli colonies, a property that correlates with its agglutinating activity for the bacterial species that were tested (Farinholt et al., 2019). Significantly, CadA appears to be secreted at the highest levels at the very edge of amoebal plaques, suggesting that it agglutinates bacteria at the plaque edge and restricts bacteria from entering the plaque. If this is idea is correct, how are the agglutinated bacteria presented to amoebae for feeding? Clues to the function of CadA at the plaque edge came from examining amoebae feeding on CadAagglutinated bacteria compared to clumps of bacteria formed mechanically by centrifugation. Vegetative amoebae surrounding ovoid clumps of bacteria is, in principle, functionally equivalent to amoebal plaques on bacterial lawns with the topology inverted. Using bacterial clumps as surrogates for the growing edges plaques, the organization imposed by CadA agglutination was observed to significantly alter amoebal predation (Farinholt et al., 2019). Amoebae chemotax more efficiently towards CadA-clumped bacteria and persist at the clump edge, feeding in an organized way from the outside of the clump inward until all of the bacteria are consumed. In stark contrast, amoebae approach mechanicallyclumped bacteria chaotically, without directed motility, and they feed by penetrating the clump, creating a "swiss cheese" effect. Interestingly, the directed motility of amoebae to CadA-clumped bacteria can be completely abolished by flooding the environment with $100-\mu \mathrm{M}$ folate, suggesting that folate is released from CadAclumped bacteria in a way that creates a chemotactic gradient. If the comparison to the plaque edge is valid, these results explain why wild-type amoebae remain inside the amoebal plaque border and migrate outward as they consume bacteria while cadA mutant amoebae migrate outside of the plaque and allow live bacteria to encroach into the plaque (Fig. 2B). The current available data indicate that $\mathrm{CadA}$ is secreted during growth on specific bacteria to create a barrier to protect the amoebae and to allow for efficient predation at the plaque edge. Presumably this barrier would form continuously at the growing plaque edge, moving as the plaque expands. D. discoideum encodes two paralogs of CadA; Cad3 (73\% amino acid identity) and Cad2 (30\% amino acid identity) (Eichinger et al., 2005). These proteins have not been studied, probably because their genes are expressed at very low levels during development, but they were identified along with $\mathrm{Cad} A$ in the sectretomes of growing amoebae (Dinh et al., 2018). Cad2 and $\mathrm{Cad} 3$ have c-terminal cadherin-related domains but are quite different in their amino acid sequences from CadA (Eichinger et al., 2005). Perhaps they carryout functions similar to CadA at the plaque edge for different species of bacteria. It would be of interest to examine the growth on different species of bacteria of the Cad single mutants, all Cad double mutant combinations, and the Cad triple mutant.

CadA is also required to temper the toxicity of its food bacteria and this may explain the low viability of $\operatorname{cad} A$ mutants. Steadystate levels of cytosolic reactive oxygen species (ROS) are much higher in $\mathrm{cad}^{-}$amoeba exposed to K. pneumoniae (Farinholt et al., 2019). Current information does not exclude the possibility that CadA functions intracellularly to moderate potential toxicity during the intracellular digestion of bacteria. However, given that the viability of cadA mutants can be restored by externally supplied CadA protein, we favor the hypothesis that its agglutinating activity is what limits the toxicity of environmental bacteria.

Though still in its early stages, the available data on the role of the plaque edge in microbiome management by $D$. discoideum suggests that amoebae form an expanding barrier as they predate on bacteria. Similar to the epithelium in the mammalian gut, this requires the secretion of lectins that agglutinate specific bacterial species, forming a moveable interface with the bacteria as amoeba grow outward. Presumably, D. discoideum uses other mechanisms to handle non-Enterobacteriaciae bacteria, possibly lectins as we suggest below, and secrete additional effectors in response to different bacteria as the plaque expands. The social amoebae's plaque barrier and human's intestinal barrier are analogous strategies for microbiome management that share the key mechanistic feature of bacteria-specific lectins that immobilize bacteria to prevent potentially harmful contact with the host (Fig. 2). Studying bacterial management at the amoebal growing edge may uncover additional mechanistic similarities that might inform studies of the human gut microbiome.

\section{Microbiome management by social amoebae during multicellular development}

Like many organisms $D$. discoideum also develops symbioses with bacteria during its multicellular phase. This manifests as a microbiome comprised of multiple species of bacteria living interand intracellularly. As described in recent work from the Strassmann and Queller laboratories, D. discoideum symbiotic bacteria afford benefits similar to the microbiomes of metazoa (Brock et al., 2011, Brock etal., 2013, Stallforth et al., 2013, DiSalvo et al., 2015, Brock et al., 2016). About $30 \%$ of $D$. discoideum strains isolated from the wild carry bacteria through their entire life cycle, within cells and in the interstitial space of aggregates and slugs, ending up as endosymbionts within encapsulated spores (Brock et al., 2011). These wild strains, termed 'carriers', feed and develop normally but maintain live populations of bacteria through repeated cycles of growth and development in the laboratory, while non-carriers remain axenic. For example, carriers harboring Burkholderia grown on lawns of fluorescently labeled K. pneumoniae food bacteria produce spores containing fluorescent bacteria. The carrier phenotype itself is infectiously induced in the amoebae by defined species of the Burkholderia genus in a manner that allows additional species of bacteria to be carried (DiSalvo et al., 2015). Several different species of Burkholderia have been isolated and characterized and they vary in their ability to induce the secondary carriage of food bacteria like K. pneumoniae (Haselkorn et al., 2018, Khojandi et al., 2019). Carried endosymbiotic bacteria, or the interstitial co-carried bacteria within sori, are hypothesized to provide a presumptive food source for the time when spores germinate and reemerge as feeding amoebae. This led to the apt initial description of carriers as "farmers" (Brock et al., 2011). The different species of carried bacteria are beneficial as they can act as a food source, they can aid in the defense against non-farmers, or induce toxin resistance (Brock et al., 2011, Brock et al., 2013, Brock et al., 2016). 

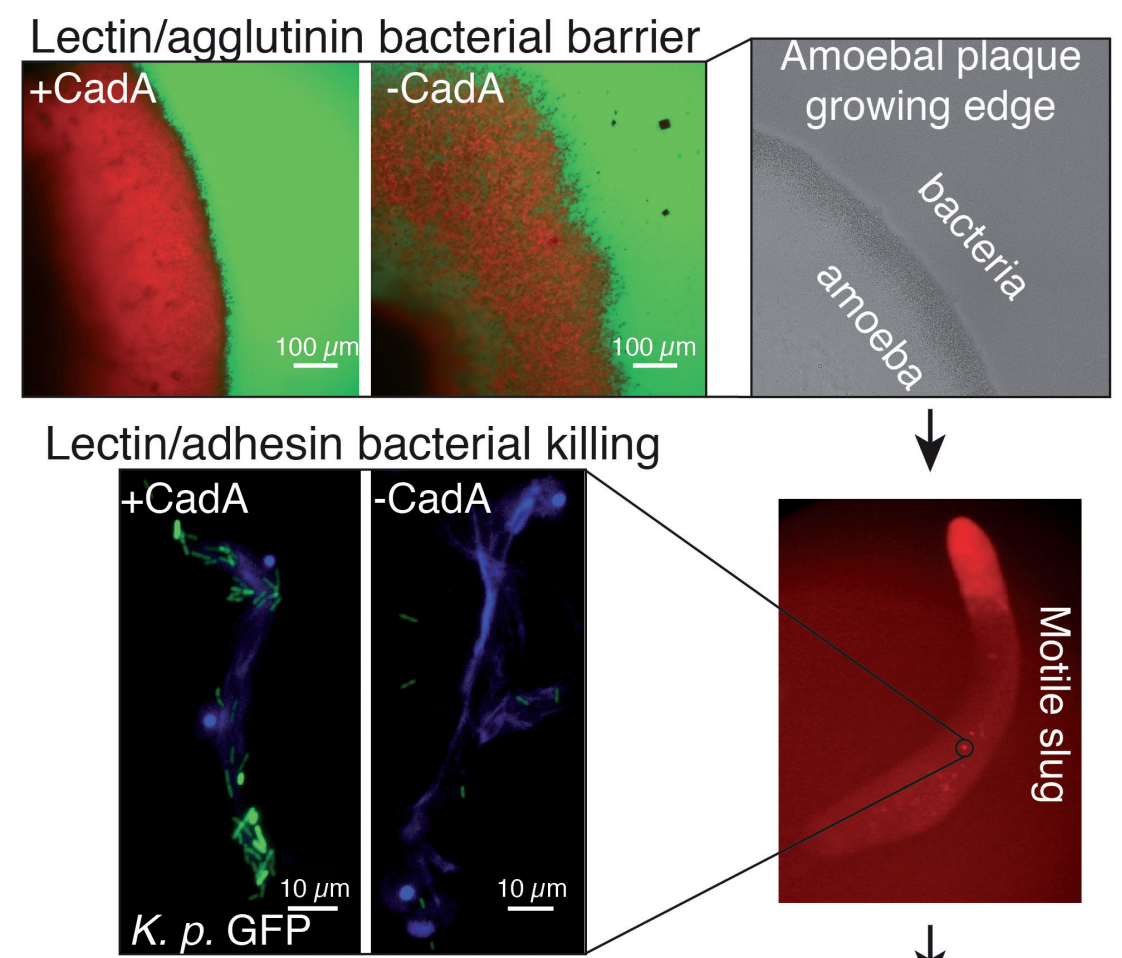

\section{ing}
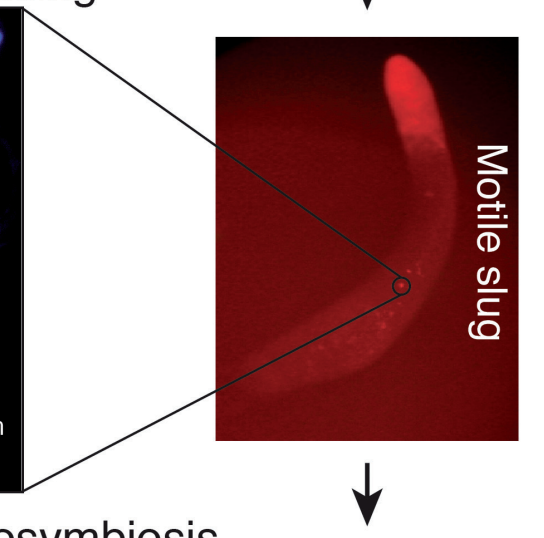

Lectin-induced bacterial endosymbiosis
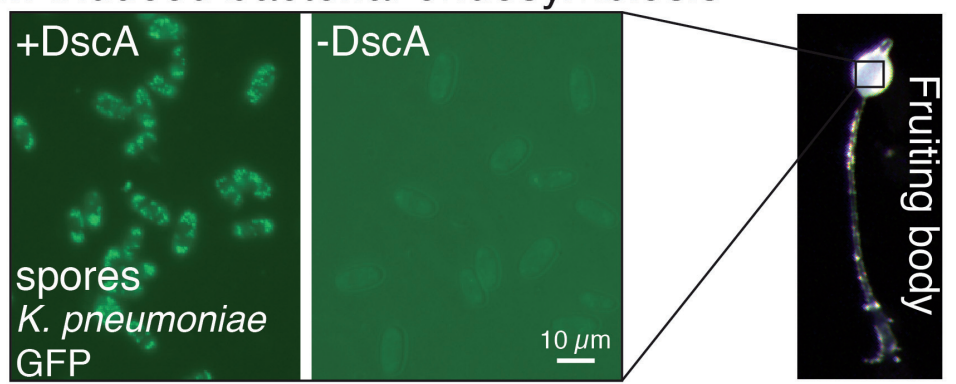

Fig. 3. Lectins determine the $D$. discoideum microbiome at different life-cycle stages. Feeding D. discoideum amoebae secrete CadA lectin that accumulates at the plaque edge that forms a transient protective interface with their food bacteria by lectin agglutination (Farinholt et al., 2019). The function of the interface can be visualized by staining for live bacteria (green) present in the bacterial lawn and dead bacteria (red) that are only found amongst the feeding wild-type amoebae ("+CadA," upper left panel). When CadA is not present, as is the case of cadA mutant plaques, the interface is not formed and live and dead bacteria are seen within the amoebal plaque ("-CadA," upper middle panell. A bright-field image of a plaque is shown also shown (upper right panel). The amoebal innate immune cells (Sentinel cells, Chen et al., 2007) patrol the mobile $\mathrm{D}$. discoideum slug (middle right panel) and produce antibacterial extracellular traps (ETS) made of mitochondrial DNA, antimicrobial proteins, and adhesins that can cause specific bacteria to bind ETs (Farinholt, 2019). CadA is one of these adhesins required for Enterobactericiae to bind to ETS, as seen with ETs produced by wild-type Sentinel cells (" +CadA", middle left panel). Enterobactericiae do not bind to the ETs produced by the Sentinel cells from cadA mutants ("-CadA", center middle panel). Another lectin, discoidin IA (DscA), binds to bacteria when added exogenously the end of the D. discoideum growth phase (+DscA) and induces bacterial endosymbiosis, in which bacteria (green) end up within the spores (lower panels; Dinh et al., 2018).

Some carried commensal bacteria protect $D$. discoideum amoebae from fungi through secretion of antifungal molecules (Stallforth et al., 2013). D. discoideum can grow on $P$. fluorescens PfB-QS161 (PfB) but not $P$. fluorescens PfA-QS161 (PfA), though both bacterial strains are carried by amoebae. Chemical characterization of PfA cultures identified pyrrolnitrin secreted in the media which is a known antifungal molecule (el-Banna and Winkelmann 1998) and which is also toxic to Acanthamoeba castelanii amoebae (Jousset et al., 2010). Since pyrrolnitrin is necessary for $P$. fluorescens to form symbiotic relationships with plants, it was plausible that a similar relationship existed with amoebae (Walsh et al., 2001; Haas and Keel 2003). Differences in toxicity of pyrrolnitrin toward carrier and non-carrier strains of $D$. discoideum would indicate adaptation to lethal symbionts. $D$. discoideum carrier strains exposed to $P$. fluorescens during growth showed no decrease in spore production, which is a proxy for overall amoebal health (Stallforth et al., 2013). Interestingly, carriers exposed to pyrrolnitrin produced more spores than control carriers that were not exposed. This suggests that $D$. discoideum carriers have adapted to a toxin from a non-food bacterium to leverage a potential antifungal fitness advantage.

\section{Induction of bacterial carriage and endosymbiosis by discoidin lectin}

Wild $D$. discoideum carrier strains make a distinctive transition from growth to development. In contrast to non-carriers, carriers initiate development before all of the food bacteria in the local environment are consumed (Brock et al., 2011). This characteristic along with the fact that the innate immune Sentinel cell population differentiates after aggregation, rendering carriage less likely, prompted the examination of vegetative cells for potential protein effectors of bacterial carriage. Indeed, the secretomes of carrier and non-carrier strains exhibit significant differences in protein content, with the most striking difference being the secretion of CadA, Cad2, Cad3, DscA, and DscC in all carriers strains that have been examined (Dinh et al., 2018). The developmental functions of the discoidin proteins and CadA have been studied for decades providing a strong foundation for investigations of their potential role(s) in microbiome management. This previous work uncovered characteristics of these proteins that predicted they might be important for mediating amoebae-bacteria interactions and their secretion during the growth of carriers was the first 
indication this is the case.

The $D$. discoideum genome contains four discoidin I genes, $d s c A, d s c C$, and $d s c D$ that produce lectins belonging to discoidin I (Discl) family, and the dscE gene that produces the discoidin II lectin (Eichinger et al., 2005, Mathieu et al., 2010, Aragao et al., 2008). All discoidin genes are developmentally induced during early developmental aggregation and during growth on Gram(-) bacteria (Rowekamp et al., 1980, Strmecki et al., 2007, Nasser et al., 2013). Early studies identified galactose-rich carbohydrate binding partners of Discl in amoebae (Barondes et al., 1974, Chang et al., 1975, Cooper et al., 1983). Immunohistochemistry has been used to co-localize Discl with the identified endogenous amoebal carbohydrates throughout development (Cooper et al., 1984). The protein localized diffusely on the cell surface of developing but not vegetative amoebae of laboratory strains. This suggests the lectin binding activity of Discl functions on the surface of the amoebae, however the protein lacks a signal sequence. Discl was later shown to be packaged in multi-lamellar bodies for secretion, likely through binding to undigested glycans remaining from food bacteria (Barondes et al., 1985). It is therefore possible that discoidin plays a role in the packaging of live bacteria into multi-lamellar bodies, for release into the environment, that has been recently been observed in D. discoideum (Paquet and Charrette 2016). In addition to its carbohydrate binding activity, a potential $\sim 67-\mathrm{kDa}$ Discl receptor was identified that interacts with Discl through protein-protein interactions (Gabius et al., 1985).

High-resolution crystal structures of ligand-free and GalNacbound DscA were successfully solved showing that DscA forms a homotrimer with the monomers in parallel orientation (Mathieu et al., 2010). Discl monomers have n-terminal Discoidin domains and c-terminal H-type lectin domains connected by a short linker. The lectin binding activity of Discl requires divalent cations and, indeed, the structure revealed $\mathrm{Ca}^{2+}$ ions at each monomer interface within the trimer suggesting a role in forming the quaternary structure (Alexander et al., 1983, Mathieu et al., 2010). It is likely that trimerization is required for carbohydrate binding as depletion of divalent cations prevents Discl from binding Sepharose 4B. While only the DscA structure has been studied DscC and DscD differ from DscA by only 13 and 9 amino acids, respectively, so they are likely to fold and trimerize in a similar manner to DscA.

Specific secretion of DscA and DscC by carriers at the growth to development transition suggested a function for these lectins in bacterial carriage. The $\mathrm{C}$-terminal $\mathrm{H}$-type lectin domain of Discl shows micromolar binding affinity to Gal $\beta 1-3$ GalNAc, a moiety found on the surface of $D$. discoideum and on bacterial cells, suggesting that Discl functions by binding to bacteria (Vinogradov et al., 2002). Indeed, DscA does bind to K. pneumoniae with micromolar affinity and to protect the bacteria from killing by antibacterial proteins produced by the same carrier cell population that secretes DscA (Dinh et al., 2018). The protection afforded bacteria by a Discl coat suggests an obvious means by which bacteria might survive predation by amoebae, leading to persistence during $D$. discoideum development. Still, it was unexpected that DscA-coated bacteria were found to induce carriage of $K$. pneumoniae by $D$. discoideum and initiate bacterial endosymbosis within amoebae. A single application of exogenous DscA to these food bacteria results in the bacteria persisting longer than lectin-free bacteria inside of vegetative amoebal cells and some bacteria remaining as live bacterial endosymbionts within encapsulated spores at the end of development (Fig. 3; Dinh et al., 2018). The process begins through an alternative bacterial uptake mechanism that we have termed lectin-induced modified bacterial internalization, or LIMBI (Dinh et al., 2018).

Our understanding of how bacteria persist through the 24-hour developmental cycle in $D$. discoideum carriers is limited. Phagocytosis mediated by lectins (lectinophagocytosis) has been described in mammals, where exogenous bacterial lectins, or plant-produced lectins, that are bound to bacteria bind to mammalian host glycoproteins prior to uptake (Bar-Shavit and Goldman 1976, Gallily et al., 1984, Ofek and Sharon 1988). Lectinophagocytosis reduces the number of bacteria killed compared to normal phagocytosis in human neutrophils suggesting protection of bacteria by lectins may be similar to LIMBI (Ofek et al., 1995). In fact, DscA-coated bacteria also undergo internalization and persist in mammalian macrophage (RAW264) cells, suggesting that LIMBI is conserved in eukaryotes (Dinh et al., 2018). Furthermore, there is also preliminarily evidence that plant lectins allow for internalization and maintenance of bacteria in mammalian cells lines suggesting that LIMBI may occur with dietary lectins in animal digestive tracts (Dinh et al., 2018). If LIMBI proves to be operational in mammals, in vivo, the means by which lectin-coated bacteria escape intracellular digestion is an important area of study that could help direct microbiome studies in humans.

Working out the intracellular handling of lectin-coated bacteria in D. discoideum is important as it is likely to be central to understanding microbiome formation. Does the binding of secreted Discl in carrier strains select for, protect, or possibly even exclude specific bacteria from carriage? It is possible that each Discl member, or indeed the other secreted lectins described below, have different affinities for different bacterial species, or that ensembles of lectin-coated bacteria work together to tailor the $D$. discoideum microbiome. Bacterial carriage induced experimentally with purified DscA also provides a possible mechanism for the carriage induced by Burkholderia, but relationship between Discl and the carriage phenotype induced by Burkholderiahas not been clarified. Precocious secretion of Discl by carriers isolated from the wild correlates with the carriage phenotype and the laboratory experiments show that DscA is sufficient for carriage, but it is unlikely that all aspects of bacterial carriage are mediated by one protein. We hypothesize that Discl mediates significant aspects of carriage because we have been able to cure wild-isolate carrier strains of their Burkholderia associates and they revert to a Discl secretion phenotype of non-carriers, that is they secrete Discl only during development (unpublished observations). Moreover, these cured strains revert back to precocious Discl secretion during growth when they are re-infected with Burkholderia. This result strengthens the correlation between Discl secretion and the carrier phenotype. Finally, the cured carriers do not carry, but they can be induced to carry $K$. pneumoniae through development with the application of exogenous DscA to these food bacteria (unpublished observations). These observations strongly suggest that Discl secretion and binding of bacteria is part of the Carrier phenotype that is induced by Burkholderia associates.

\section{Bacterial extracellular traps in amoebae and humans}

Mammalian innate immune systems consist of motile tissue resident or free circulating cells such as neutrophils, basophils, mac- 
rophages, and eosinophils. These cells chemotax toward chemical signals (e.g. IL-8 and hydrogen peroxide) released by cells at the site of acute infection (Kienle and Lämmermann 2016, Vargas et al., 2017, Yousefi et al., 2008, Yousefi et al., 2009, Yousefi et al., 2012). Upon arrival they phagocytose bacteria, secrete antimicrobial proteins and peptides, and release reticulated DNA extracellular traps (ETs) that bind and kill bacteria (Brinkmann et al., 2004). Neutrophils rapidly release ETs coated with azurophilic granule proteins through an unknown mechanism (Papayannopoulos 2018). The reticulated DNA provides structure, allowing antimicrobials to be delivered directionally without diffusion into the surrounding tissues. Stimulation of toll-like receptors (TLRs) by pathogens leads to the release of reactive oxygen species by the NADPH oxidase, Nox2 (Brinkmann et al., 2004, Shiu and Gaspari 2017). Genetic ablation or pharmacological inhibition of NADPH oxidase activity blocks the release of ETs (Amini et al., 2018).

Some bacterial strains evolved methods to avoid killing by ETs. GroupA Streptococcus, a causative pathogen in necrotizing fasciitis (NF), produces a strong DNase (Sda1) that rapidly destroys ET structures rendering them inert (Buchanan et al., 2006). This may explain the correlation between DNase expression and a bacterial strain's virulence. Another means of avoiding phagocytosis that bacteria often employ is aggregation, necessitating killing by ETs. For example, Mycobacterium bovis aggregates stimulate ETosis in a size dependent manner and ETosis in the lungs was only observed following exposure to clumps of Klebsiella pneumoniae and not planktonic bacteria (Branzk et al., 2014, Papayannopoulos et al., 2010). These data indicate ETosis is important for handling difficult to phagocytize bacteria.

Precise physiologic control of ET release is important as underor over-activation results in disease. Patients with chronic granulomatous disease (CGD) or myeloperoxidase deficiency present with widespread bacterial and fungal infections (Metzler et al., 2011, Fuchs et al., 2007). Regaining NADPH oxidase activity by gene therapy restores ET production and alleviates chronic lung infections (Bianchi et al., 2011). Increased presence of ETs through erroneous release, or decreased ET clearance efficiency, can lead to vasculitis (Kessenbrock et al., 2009), thrombosis (Fuchs et al., 2010, Martinod and Wagner 2013), lupus nephritis (Hakkim et al., 2010), and are causative in the pathophysiology of cystic fibrosis (Law and Gray 2017).

Slugs of carrier strains present an interesting opportunity to study microbiome maintenance in the presence of an innate immune system. For interstitial bacteria to survive during the development of carriers they must evade the Sentinel cells that 'patrol' migrating slugs and remove bacteria either by phagocytosis or by killing them on extracellular DNA traps (Chen et al., 2007, Zhang et al., 2016, Zhang and Soldati 2016). Sentinel cells were discovered when slugs were made to traverse across agar containing fluorescent dies as proxies for environmental toxins. Concentrated fluorescent puncta were observed in slugs travelling across the agar that were continuously deposited behind the slug in the slime sheath but maintained a constant number within the slug (Chen et al., 2007). Similar to phagocytic cell types in the human innate immune system, Sentinel cells use phagocytosis to clear the slug of harmful bacteria and toxins. Constant numbers of $\mathrm{S}$ cells are observed in slugs traveling over long periods of time suggesting that Sentinel cells continually differentiate (Chen et al., 2007). Sentinel cells isolated from slugs migrating over ethidium bromide agar have a higher mutation rate and lower viability compared to non-Sentinel cells from the same slugs so it has been hypothesized that Sentinel cells protect slugs by sacrificing their own viability as they sequester toxins (Chen et al., 2007).

Key cellular requirements for ET release from Sentinel cells appear to be conserved with humans. As with humans, D. discoideum ET release requires ROS produced by NADPH oxidase (Zhang et al., 2016). The D. discoideum genome has three genes that encode NADPH oxidases (NoxA, NoxB, NoxC) that are each homologous to human Nox2 (Lardy et al., 2005), and NoxABC-KO triple mutants are defective in ET release (Zhang et al., 2016). The addition of exogenous catalase enzyme to Sentinel cells also suppresses their ET production, supporting this genetic inference (Zhang et al., 2016). TLR signaling is also a shared requirement between amoebae and humans since signaling through the one Toll/Interleukin-1 receptor (TIR) domain protein in $D$. discoideum (TirA) is required for ET release (Zhang et al., 2016). That ETs are required to eliminate bacteria during $D$. discoideum development comes from the findings that tir $A^{-}$mutants are more sensitive to killing by $L$. pneumophila and tir $A^{-}$and nox $A B C$ mutants contain live bacteria in their developing structures (Chen et al., 2007, Zhang et al., 2016). These data indicate that ETs do in fact play a role in microbiome management during $D$. discoideum development and suggests the innate immune function they provide can be overcome by Burkholderia induction of bacterial carriage, or by DscA-mediated LIMBI.

So how do carriers maintain a microbiome in the presence of an innate immune system in the slug? It turns out that carrier slugs have a smaller percentage of Sentinel cells compared to noncarriers suggesting that a characteristic of the carrier phenotype is lower levels of Sentinel cell differentiation (Brock et al., 2016, Dinh et al., 2018). Although, reduced Sentinel cell populations would be expected to increase susceptibility to environmental toxins in carriers, the spore deficit of carrier strains harboring Burkholderia does not worsen in the presence of toxins whereas non-carriers display reduced spore production in the presence of toxins (Brock et al., 2016). This suggests that the $D$. discoideum microbiome may benefit host cells during development by providing detoxifying activity directly or by inducing increased toxin resistance in the host cells. There is some recent evidence that such benefits result from co-evolution of carrier amoebae with specific species of Burkholderia (Shu et al., 2018).

Anumber of studies have focused on identifying proteins associated with ETs that decorate the structure and provide antimicrobial activity (e.g., Papayannopoulos 2018). While ET-associated antimicrobials have been identified, much less is known about factors regulating bacterial adherence to ETs. Adherence of bacteria to ETs exposes them to high local concentrations of antimicrobials allowing for efficient killing, so understanding how bacteria associate with ETs is potentially important for understanding how ETs kill bacteria. It is thought the reticulated DNA structure of ETs is naturally 'sticky', but there have been no studies that address this potential mechanism directly. CadA was identified as an ETassociated protein in a crude purification of $D$. discoideum $E T s$ and given the bacterial agglutination function of $\mathrm{CadA}$, it was plausible that bacterial adhesion to ETs was mediated by CadA. Indeed, there is a clear correlation between the agglutination of bacteria by $\mathrm{Cad} A$ and a requirement for $\mathrm{Cad} A$ in the adherence of those species of bacteria to ETs (Farinholt, 2019). K. pneumoniae and E. 
TABLE 1

\section{SECRETED LECTINS OF D. DISCOIDEUM}

\begin{tabular}{|c|c|c|c|}
\hline Protein Family (members) & Mutant Phenotype & Lectin Class & Reference(s) \\
\hline Cadherin (CadA, Cad2, Cad3) & Low viability on Gram(-) (cadA-) & Cadherin-related & Farinholt et al., 2019 \\
\hline Discoidin I (DscA, DscC, DscD) & Slow growth on Gram(-) (dscA-D antisense strain) & H-type (C-terminus); F-type (N-terminus) & Mathieu, et al., 2010; E. Nam, unpublished \\
\hline IliE (IliE-1, IliE-2) & No growth on Gram(+) (iliE1-) & Concanavalin A & Farbrother et al., 2006; Nasser et al., 2013 \\
\hline Cup (CupA-J) & No mutant [produced on Gram(-)] & Ricin B & C. Dinh, unpublished \\
\hline
\end{tabular}

coli do not adhere to ETs produced by cadA- mutants while other species were indifferent to the presence of CadA. Additionally, exogenous $\mathrm{CadA}$ added to $\mathrm{ETs}$ produced by cad $A^{-}$cells restores the adherence of $K$. pneumoniae and E. coli. Moreover, cadA- ETs killed $K$. pneumoniae at a significantly less efficiently, but this deficiency can be rescued by adding exogenous CadA protein back to the assay. These data indicate efficient killing of specific bacterial species by ETs requires adherence through a specific binding protein, allowing $D$. discoideum ETs to work as bacterial "flypaper". CadA is the first example of an ET-associated bacterial adhesion protein, and this opens up the possibility of uncovering additional such proteins that are necessary for ET function both in amoebae and possibly in humans. For example, $P$. aeruginosa and $M$. luteus are agnostic to CadA's presence on $D$. discoideum ETs so other proteins, possibly lectins, are likely needed for adhesion of these bacteria.

Conservation of immune cell ET function from amoebae to humans indicates common selective pressure served to preserve this defense strategy in evolution (Brinkmann et al., 2004, Palic et al., 2007, Chuammitri et al., 2009). If $D$. discoideum $E$ Ts are in fact homologous to human ETs it would put the advent of ETs back to over 1 billion years ago (Zhang and Soldati 2016). Conservation of the cellular requirements for ET release suggests that further study using genetically tractable amoebae will identify novel regulators in humans. The discovery of a new bacteria-specific ET adhesion protein offers the motivation to seek out similar accessory proteins in humans, which may translate into a better understanding of how ETs prevent (and cause) disease in humans.

\section{Microbiome control by lectins}

Microbiome management requires that hosts recognize speciesspecific molecules that are abundant on the bacterial surface, so cell surface glycans make optimal targets. Bacteria have abundant surface carbohydrates such as the lipopolysaccharide (LPS) of the Gram(-) bacteria K. pneumoniae (Vinogradov et al., 2002). These polymers of monosaccharides (e.g. glucose, galactose, mannose, etc.) have a variety of chemical linkages and conformations. Given the variation of glycans and their potential as unique identifiers it is no wonder that early immune signaling employed carbohydratebinding lectins to decipher microbially complex environments. Lectins have been identified in the genomes of almost every organism, functioning in numerous biological pathways (Abhinav et al., 2016, Xia et al., 2017, Breitenbach et al., 2018). The evolutionary ramification of lectins has resulted in over 20 different families that have been classified based on their saccharide binding specificity and structure of the carbohydrate recognition domains, many of which are present in D. discoideum (Eichinger et al., 2005).

An incomplete patchwork of data suggests that lectins evolved as early immune molecules that are still used by humans for microbiome management. And while the method of bacterial recognition in humans has evolved to use more specific cellular systems, secreted lectins are still used for microbial control on epithelial surfaces. Lectins have been identified as important antimicrobials in the human gut, such as Reglll $\gamma$ discussed above, targeting specific bacteria through lectin binding and preferential elimination of pathogenic bacteria (Cash et al., 2006, Miki et al., 2012, Mukherjee et al., 2014). Given the diversity and the versatility in glycan binding that the lectins encompass it is tempting to speculate that they have additional roles in modulating metazoan microbiomes, beyond sequestration and elimination functions, such as the maintenance of specific bacterial ensembles.

Transcriptomic and proteomic studies have identified at least four families of lectins that $D$. discoideum expresses or secretes in response to exposure to different bacterial species (Table 1). In addition to CadA and DscA described above, iliE encodes a concanavalin A homolog that was identified by differential expression analysis to be expressed during growth on Gram(+) bacteria, suggesting a role for lliE in protection from, predation on, or digestion of Gram(+) bacteria (Nasser et al., 2013). Moreover iliE mutants are unable to grow on lawns of $\operatorname{Gram}(+)$ bacteria which predicts that IliE-1 and IliE-2 have lectin activity and bind to Gram(+) bacteria, like concanavalin A (Nasser et al., 2013, Doyle and Birdsell 1972). It is also worth considering that IliE proteins function like CadA and form a protective barrier at the plaque edge when $D$. discoideum amoebae are growing on lawns of Gram(+) bacteria. Another predicted lectin gene family are encoded by the cupgenes, cupA-J, which are predicted to contain a ricin B superfamily domain found in AB toxin systems, glycosidases, and proteases (Hazes and Read 1995, Hazes 1996, Hirabayashi et al., 1998). These proteins were identified as being secreted after exposure of $D$. discoideum amoebae to Gram(-) bacteria (C. Dinh, unpublished). They represent another family of lectins that should be examined for roles in microbiome control. For the myriad of lectins that amoebae secrete, glycan-mediated 'pulldown' proteomics might be useful for identifying which bacterial glycans each of these lectins bind (Gesslbauer et al., 2016, Lopez Aguilar et al., 2017).

There is the possibility for significant regulatory flexibility in microbiome control in $D$. discoideum with the 18 identified lectins distributed amongst four lectin protein families. Lectin function could also be expanded by lectin-lectin interactions. While only DscA has been directly demonstrated to be sufficient for carriage, the high degree of similarity of DscC and DscD to DscA suggests these two lectins will be involved as well. For the discoidins, many possible heterotrimers are theoretically possible given the similarity in primary amino acid sequence. Such discoidin hetero trimers, and indeed the three homotrimers, may functionally interact by binding the same species of bacteria, or different species, affording the amoebae opportunity to fine-tune the composition of their microbiome. Differential secretion of DscA, DscC, and DscD 
homotrimers elicited by different bacteria may provide additional avenues of regulation. Given the coordinate secretion of $\mathrm{CadA}$, Cad2, Cad3, DscA and DscC during the growth to development transition these lectins may influence each other's function directly. For example, the agglutination of bacteria by $\mathrm{CadA}$ at the growing edge may block the binding of DscA while bacterial densities are high. Following depletion of the bacteria, agglutination by $\mathrm{CadA}$ would become less efficient allowing Discl proteins to coat bacteria and induce carriage.

\section{Summary}

The existence of microbiomes throughout eukaryotic species and their importance to the survival of those species allows us to study evolutionarily conserved aspects in simpler model organisms such as $D$. discoideum. Multiple systems operate within the human gut to prevent bacteria from escaping the lumen and penetrating into the tissues, and any defect in those functions leads to debilitating inflammatory diseases. It appears that $D$. discoideumalso employs multiple mechanisms to control its bacterial microbiome during growth and during development to moderate bacterial toxicity. The dynamics in bacterial composition of the microbiome is also similar in the two systems in that the inclusion or exclusion of a bacterium depends on the presence of other bacterial species. The amoebal plaque edge is analogous to the human gut epithelium with dense bacterial populations apposed to a thin border of amoebal cells (Figure 2). In both species, the barrier function that depends on host-derived lectins allows bacteria to be used as food directly (social amoeba) or provide nutrients indirectly (humans) while preventing direct exposure to host cells - the intestinal mucosa or the interior of the amoebal plaque. The mechanistic similarities between $D$. discoideum effectors in the soil and human effectors in the gut suggests that novel findings in social amoebae may translate into a deeper understanding of the management of microbiome homeostasis in humans.

\section{References}

ABDIAN P L, CARAMELO J J, AUSMEES N, ZORREGUIETA A (2013). RapA2 is a calcium-binding lectin composed of two highly conserved cadherin-like domains that specifically recognize Rhizobium leguminosarum acidic exopolysaccharides. J Biol Chem 288: 2893-2904.

ABHINAV K V, SAMUEL E, VIJAYAN M (2016). Archeal Lectins: An Identification through a Genomic Search. Proteins 84: 21-30.

ADIBA S, NIZAK C, VAN BAALEN M, DENAMUR E, DEPAULIS F (2010). From Grazing Resistance to Pathogenesis: The Coincidental Evolution of Virulence Factors. PLOS ONE 5: 1-10.

ALEXANDER S, CIBULSKY A M, LERNER R A (1983). Ion Dependence of the Discoidin I Lectin from Dictyostelium Discoideum. Differentiation 24: 209-212.

AMBORT D, JOHANSSON M, GUSTAFSSON J K, ERMUND A, HANSSON G C (2012). Perspectives on Mucus Properties and Formation-Lessons from the Biochemical World. CSH Perspec. Med. 2: 1-10.

AMINI P, STOJKOV D, FELSER A, JACKSON C B, COURAGE C, SCHALLER A, GELMAN L, SORIANO M E, NUFFER J-M, SCORRANO L, BENARAFA C, YOUSEFI S, SIMON H-U (2018). Neutrophil extracellular trap formation requires OPA1-dependent glycolytic ATP production. Nat Commun 9: 2958.

ARAGÃO K S, SATRE M, IMBERTY A, VARROTA (2008). Structure Determination of Discoidin II from Dictyostelium Discoideum and Carbohydrate Binding Properties of the Lectin Domain. Proteins 73: 43-52.

BARONDES S H, HAYWOOD-REID P L, COOPER D N W (1985). Discoidin I, an Endogenous Lectin, is externalized from Dictyostelium discoideum in multilamellar bodies. J Cell Biol 100: 1825-1833.
BARONDES S H, SIMPSON D L, ROSEN S D (1974). Discoidin, a developmentally regulated carbohydrate-binding protein from Dictyostelium discoideium. purification and characterization. Biochem. 13: 3487-3493.

BAR-SHAVIT Z, GOLDMAN R (1976). Concanavalin A-mediated attachment and ingestion of yeast cells by macrophages. Exp Cell Res 99: 221-236.

BIANCHI M, NIEMIEC MJ, SILER U, URBAN CF, REICHENBACH J (2011). Restoration of anti-Aspergillus defense by neutrophil extracellular traps in human chronic granulomatous disease after gene therapy is calprotectin-dependent. J Allergy Clin Immunol 127: 1243-1252.

BIOLEY G, MONNERAT J, LOTSCHERM, VONARBURG C, ZUERCHERA, CORTHESYB (2017). Plasma-derived polyreactive secretory-like Iga and IgM opsonizing Salmonella enterica typhimurium reduces invasion and gut tissue inflammation through agglutination. Front Immunol 8: 1-11.

BOULAIS J, TROST M, LANDRY C R, DIECKMANN R, LEVY E D, SOLDATI T, MICHNICK S W, THIBAULT P, DESJARDINS M (2010). Molecular characterization of the evolution of phagosomes. Mol Syst Biol 6:423. doi:10.1038/msb.2010.80

BOZZARO S, EICHINGER L (2011). The professional phagocyte Dictyostelium discoideum as a model host for bacterial pathogens. Curr Drug Target 12: 942-954.

BRANZK N, LUBOJEMSKAA, HARDISON SE, WANG Q, GUTIERREZ MG, BROWN GD, PAPAYANNOPOULOS V (2014). Neutrophils sense microbe size and selectively release neutrophil extracellular traps in response to large pathogens. Nat Immun 15: 1017-1125.

BREITENBACH BARROSO COELHO L C, MARCELINO DOS SANTOS SILVA P, FELIXDE OLIVEIRAW, D E MOURAM C, VIANAPONTUALE, SOARES GOMES F, GUEDES PAIVA P M, NAPOLEAO T H, DOS SANTOS CORREIA M T (2018), Lectins as antimicrobial agents. J Appl Microbiol 125: 1238-1252.

BRINKMANN V, REICHARD U, GOOSMANN C, FAULER B, UHLEMANN Y, WEISS DS, WEINRAUCH Y, ZYCHLINSKY A (2004). Neutrophil extracellular traps kill bacteria. Science 303: 1532-1535.

BROCK D A, DOUGLAS T E, QUELLER D C, STRASSMANN J E (2011). Primitive agriculture in a social Amoeba. Nature 469: 393-396.

BROCK D A, READ, S, BOZHCHENKO A, QUELLERDC, STRASSMANN J E (2013). Social amoeba farmers carry defensive symbionts to protect and privatize their crops Nat Comm 4: 1-7.

BROCK D A, CALLISON W E, STRASSMANN J E, QUELLER D C (2016). Sentine cells, symbiotic bacteria and toxin resistance in the social amoeba Dictyostelium discoideum. Proc Royal Soc B: Biol Sci283: 20152727. doi: 10.1098/rspb.2015.2727

BROWN G D, WILLMENT J A, WHITEHEAD L (2018). C-type lectins in immunity and homeostasis. Nat Rev. Immunol 2018 18: 374-389.

BUCHANAN J T, SIMPSON A J, AZIZ R K, LIU G Y, KRISTIAN S A, KOTB M, FERAMISCO J, NIZET V (2006). DNase expression allows the pathogen group A Streptococcus to escape killing in neutrophil extracellular traps. Curr Biol 16: 396-400.

CASADEVALL A, PIROFSKI LA (2007). Accidental virulence, cryptic pathogenesis, martians, lost hosts, and the pathogenicity of environmental microbes. Euk Cell 6: 2169-2174.

CASH H L, WHITHAM C V, BEHRENDT C L, HOOPERL V (2006). Symbiotic bacteria direct expression of an intestinal bactericidal lectin. Science 313: 1126-1130.

CHANG, CM, REITHERMAN RW, ROSEN SD, BARONDES S H (1975). Cell surface location of discoidin, a developmentally regulated carbohydrate-binding protein from Dictyostelium Discoideum. Expt. Cell Res 95: 136-142.

CHEN G, ZHUCHENKO O, KUSPA A (2007). Immune-like phagocyte activity in the social amoeba. Science 317: 678-681.

CHILEVERU H R, LIM S A, CHAIRATANA P, WOMMACK A J, CHIANG I L, NOLAN E M (2015). Visualizing Attack of Escherichia Coli by the Antimicrobial Peptide Human Defensin 5. Biochem 54: 1767-1777.

CHU H, PAZGIER M, JUNG G, NUCCIO S-P, CASTILLO PA, DE JONG M F, WINTER M G, WINTER S E, WEHKAMP J, SHEN B, SALZMAN N H, UNDERWOOD M A, TSOLIS RM, YOUNG G M, LU W, LEHRER R I, BAUMLER A J, BEVINS C $L$ (2012). Human $\alpha$-Defensin 6 promotes mucosal innate immunity through selfassembled peptide nanonets. Science 337: 477-481.

CHUAMMITRI P, OSTOJIC J, ANDREASEN C B, REDMND S B, LAMONT S J, PALIC D (2009). Chicken heterophil extracellular traps (HETs): novel defense mechanism of chicken heterophils. Vet. Immunol Immunopath 129: 126-131.

CLARKEM (2010). Recent insights into host-pathogen interactions from Dictyostelium. Cell Microbiol 12: 283-291. 
COOPERD NW, LEE SC, BARONDES SH (1983). Discoidin-binding polysaccharide from Dictyostelium discoideum. J Biol Chem 258: 8745-8750.

COOPER D N W, BARONDES S H (1984). Colocalization of discoidin-binding ligands with discoidin in developing Dictyostelium discoideum. Dev. Biol 105: 59-70.

CORFIELD, A P (2013). Mucins: a biologically relevant glycan barrier in mucosal protection. Biochimica et Biophysica Acta 1850: 236-252.

CORFIELD A P (2018). The Interaction of the Gut microbiota with the mucus barrier in health and disease in human. Microorganisms 6: 0078. doi:10.3390/microorganisms6030078

Cosson P, Soldati T (2008). Eat, Kill or Die: When Amoeba Meets Bacteria. Curr Opin Microbiol 11: 271-276.

DINH C, FAIRINHOLT T, HIROSE S, ZHUCHENKO O, KUSPA A (2018). Lectins Modulate the Microbiota of Social Amoebae. Science 361: 402-406.

DISALVO S, HASELKORN T S, BASHIR U, JIMENEZ D, BROCK D A, QUELLER D C, STRASSMANN J E (2015). Burkholderia Bacteria Infectiously Induce the Proto-Farming Symbiosis of Dictyostelium Amoebae and Food Bacteria. Proc Natl Acad Sci USA 112: 5029-5037.

DOMINGUEZ-BELLO M G, GODOY-VITORINO F, KNIGHT R, BLASER M J (2019). Role of the microbiome in human development. Gut 68: 1108-1114.

DOYLE, R J, BIRDSELL D C (1972). Interaction of concanavalin A with the cell wall of Bacillus subtilis. J Bacteriol 109: 652-658.

EICHINGER L, PACHEBAT J A, GLÖCKNER G, RAJANDREAM M A, SUCGANG R, BERRIMAN M, SONG J, OLSEN R, SZAFRANSKI K, XU Q, TUNGGAL B, KUMMERFELD S, MADERA M, KONFORTOV B A, RIVERO F, BANKIER A T, LEHMANN R, HAMLIN N, DAVIES R, GAUDET P, FEY P, PILCHER K, CHEN G, SAUNDERS D, SODERGREN E, DAVIS P, KERHORNOU A, NIE X, HALL N, ANJARD C, HEMPHILL L, BASON N, FARBROTHER P, DESANY B, JUST E, MORIOT, ROSTR, CHURCHER C, COOPER J, HAYDOCKS, VAN DRIESSCHE N, CRONIN A, GOODHEAD I, MUZNY D, MOURIER T, PAIN A, LU M, HARPER $D$, LINDSAY R, HAUSER H, JAMES K, QUILES M, MADAN BABU M, SAITO T, BUCHRIESER C, WARDROPER A, FELDER M, THANGAVELU M, JOHNSON D, KNIGHTS A, LOULSEGED H, MUNGALL K, OLIVER K, PRICE C, QUAIL MA, URUSHIHARA H, HERNANDEZ J, RABBINOWITSCH E, STEFFEN D, SANDERS M, MA J, KOHARA Y, SHARP S, SIMMONDS M, SPIEGLER S, TIVEY A, SUGANO S, WHITE B, WALKER D, WOODWARD J, WINCKLER T, TANAKA Y, SHAULSKY G, SCHLEICHER M, WEINSTOCK G, ROSENTHAL A, COX E C, CHISHOLM R L, GIBBS R, LOOMIS W F, PLATZER M, KAY R R, WILLIAMS J, DEAR P H, NOEGEL A A, BARRELL B, KUSPA A (2005). The genome of the social amoeba Dictyostelium discoideum. Nature $435:$ 43-57.

EL-BANNA N, WINKELMANN G (1998). Pyrrolnitrin from Burkholderia cepacia: antibiotic activity against fungi and novel activities against Streptomycetes. $J$ Appl Microbiol 85: 69-78.

ERICKSEN B, WU Z, LUW, LEHRER RI (2005). Antibacterial activity and specificity of the antibacterial activity and specificity of the six. Antimicrob. Agents Ch. 49:8-15.

FARBROTHER P, WAGNER C, NA J, TUNGGAL B, MORIO T, URUSHIHARA H, TANAKAY, SCHLEICHER M, STEINERT M, EICHINGER L (2006). Dictyostelium transcriptional host cell response upon infection with I. Cell Microbiol 8: 438-456.

FARINHOLT T (2019). How social amoebae manage diverse bacterial interactions with secreted lectins. Ph.D. thesis, Baylor College of Medicine, Houston Texas USA. pp. 1-211

FARINHOLT T, DINH C, KUSPA A (2019). Social amoebae establish a protective interface with their bacterial associates by lectin agglutination. Sci Advances 5: eaav4367.

FUCHS T A, ABED U, GOOSMAN C, HURWITZ R, SCHULZE I, WAHN V, WEINRAUCH Y, BRINKMANN V, ZYCHLINSKY A (2007). Novel cell death program leads to neutrophil extracellular traps. J Cell Biol 176: 231-241.

FUCHS T A, BRILL A, DUERSCHMIED D, SCHATZBERG D, MONESTIER M, MYERS D D, WROBLESKI S K, WAKEFIELD T W, HARTWIG J H, WAGNER D D (2010). Extracellular DNA traps promote thrombosis. Proc Natl Acad Sci USA 107: 15880-15885.

GABIUS H J, SPRINGER W R, BARONDES S H (1985). Receptor for the cell binding site of discoidin I. Cell 42: 449-456.

GALLILY R, VRAY B, STAIN I, SHARON N (1984). Wheat germ agglutinin potentiates uptake of bacteria by murine peritoneal macrophages. Immunol 52: 679-686.

Gassler N (2017). Paneth cells in intestinal physiology and pathophysiology. World J Gastro Pathophysiol 8: 150-160.
GESSLBAUER B, DERLER R, HANDWERKER C, SELES E, KUNGL A J (2016) Exploring the glycosaminoglycan-protein interaction network by glycan-mediated pull-down proteomics. Electrophoresis 37: 1437-1447.

GREUB G, RAOULT D (2004). Microorganisms resistant to free-living amoebae. Clin Microbiol Rev 17: 413-433.

HAAS D, KEEL C (2003). Regulation of Antibiotic Production in Root-Colonizing Pseudomonas Spp. and Relevance for Biological Control of Plant Disease. Ann Rev Phytopathol 41: 117-153.

HAKKIM A, FURNROHR B G, AMANN K, LAUBE B, ABED U A, BRINKMANN V, HERRMANN M, VOLL R E, ZYCHLINSKY A (2010). Impairment of neutrophil extracellular trap degradation is associated with lupus nephritis. Proc Natl Acad Sci USA 107: 9813-9818.

HARRISON C F, CHIRIANO G, FINSEL I, MANSKE C, HOFFMANN C, STEINER B, KRANJC A, PATTHEY-VUADENS O, KICKA S, TROFIMOV V, OUERTATANISAKOUHI H, SOLDATI T, SCAPOZZA L, HILBI H (2015). Amoebae-based screening reveals a novel family of compounds restricting intracellular Legionella pneumophila. ACS Infect Dis 1: 327-338.

HÄGELE S, KOHLER R, MERKERT H, SCHLEICHER M, HACKER J, STEINERT M (2000). Dictyostelium discoideum: a new host model system for intracellular pathogens of the genus Legionella. Cell Microbiol 2: 165-71.

HASELKORN T S, DISALVO S, MILLER J W, BASHIR U, BROCK D A, QUELLER D C, STRASSMANN J E (2019). The specificity of Burkholderia symbionts in the social amoeba farming symbiosis: Prevalence, species, genetic and phenotypic diversity. Mol Ecol 28: 847-862.

HAZES B, READ RJ (1996). A mosquitocidal toxin with a ricin-like cell-binding domain. Nat Struct Biol 2: 358-359.

HAZES B (1996). The (QXW)3 domain: a flexible lectin scaffold. Protein Sci. 5 : 1490-1501.

HIRABAYASHI J, DUTTA S K, KASAI K (1998). Novel galactose-binding proteins in Annelida. Characterization of 29-kDa tandem repeat-type lectins from the earthworm Lumbricus terrestris. J Biol Chem 273: 14450-14460.

JOHANSSON M E, PHILLIPSON M, PETERSSON J, VELCICH A, HOLM L, HANSSON G C (2008). The Inner of the Two Muc2 Mucin-Dependent Mucus Layers in Colon Is Devoid of Bacteria. Proc Natl Acad Sci USA 105: 15064-15069.

JOUSSETA, ROCHAT L, SCHEU S, BONKOWSKI M, KEELC (2010). Predator-Prey Chemical Warfare Determines the Expression of Biocontrol Genes by RhizosphereAssociated Pseudomonas Fluorescens. Applied and EnvirMicrobio/76:5263-5268.

KATOH M, CHEN G, ROBERGE E, SHAULSKY G, KUSPA A 2007. Developmental commitment in Dictyostelium discoideum. Euk Cell 6: 2038-2045.

KESSIN R H (2001). Dictyostelium - Evolution, Cell Biology, and the Development of Multicellularity. UK: Cambridge Univ Press: Cambridge.

KESSENBROCK K, KRUMBHOLZM, SCHONERMARCK U, BACK W, GROSS W L, WERB Z, GRONE H J, BRINKMANN V, JENNE D E (2009). Netting neutrophils in autoimmune small-vessel vasculitis. Nat Med 15: 623-625.

Khojandi N, Haselkorn T S, Eschbach M N, Naser, RA, DiSalvo S (2019). Intracellular Burkholderia Symbionts induce extracellular secondary infections; driving diverse host outcomes that vary by genotype and environment. ISME J.13: 2068-2081.

KIENLE K, LÄMMERMANN T (2016). Neutrophil swarming: an essential process of the neutrophil tissue response. Immunol Rev 273: 76-93.

LANG T, KLASSON S, LARSSON E, JOHANSSON M E, HANSSON G C, SAMUELSSON T (2016). Searching the evolutionary origin of epithelial mucus protein components - mucins and FCGBP. Mol Biol Evol 33: 1921-1936.

LANGDON A, CROOK N, DANTAS G (2016). The Effects of Antibiotics on the Microbiome throughout Development and Alternative Approaches for Therapeutic Modulation. Genome Med 8: 39. doi: 10.1186/s13073-016-0294-z.

LARDY B, BOF M, AUBRY L, PACLET MH, MOREL F, SATRE M, KLEIN G (2005). NADPH oxidase homologs are required for normal cell differentiation and morphogenesis in Dictyostelium discoideum. Biochim Biophys Acta 1744: 199-212.

LAWSM, GRAYRD (2017). Neutrophil extracellular traps and the dysfunctional innate immune response of cystic fibrosis lung disease:A review. J Inflamm (UK) 14: 1-8.

LEY R E, HAMADY M, LOZUPONE C, TURNBAUGH P J, RAMEY R R, BIRCHER J S, SCHLEGEL M L, TUCKER T A, SCHRENZEL M D, KNIGHT R, GORDON J I (2008). Evolution of mammals and their gut microbes. Science 320: 1647-1651.

LIN Z, SRISKANTHADEVAN S, HUANG H, SIU C-H, YANG D (2006). Solution structures of the adhesion molecule DdCAD-1 reveal new insights into $\mathrm{Ca}(2+)$ - 
dependent cell-cell adhesion. Nat Struct \& Mol Biol 13: 1016-1022.

LOPEZ AGUILAR A, BRIARD J G, YANG L, OVRYN B, MACAULEY M S, WU P (2017). Tools for studying glycans: recent advances in chemoenzymatic glycan labeling. ACS Chem Biol 12: 611-621.

MARKMAN D W, ANTOLIN M F, BOWEN RA, WHEAT WH, WOODS M, GONZALEZJUARRERO M, JACKSON M (2018). Yersinia pestis survival and replication in potential amoeba reservoir. Emerg Infect Dis 24: 294-302.

Martinod K, Wagner DD (2011). Thrombosis: tangled up in NETs. Blood 123:2768-2776.

MASUDA K, SAKAI N, NAKAMURA K, YOSHIOKA S, AYABE T (2011). Bactericidal activity of mouse $\alpha$-defensin cryptdin-4 predominantly affects noncommensal bacteria. J Innate Immun 3: 315-326.

MATHIEU S V, ARAGÃO K S, IMBERTY A, VARROT A (2010). Discoidin I from Dictyostelium discoideum and interactions with oligosaccharides: specificity, affinity, crystal structures, and comparison with discoidin II. J Mol Biol 400: 540-554.

MAYER S, RAULF M K, LEPENIES B 2017. C-Type lectins: their network and roles in pathogen recognition and immunity. Histochem Cell Biol 147: 223-237.

MCCAULEY H A, GUASCH G (2015). Three cheers for the goblet cell: maintaining homeostasis in mucosal epithelia. Trends in Mol Med 21: 492-503.

METZLER K D, FUCHS TA, NAUSEEF W M, REUMAUXD, ROESLER J, SCHULZE I, WAHN V, PAPAYANNOPOULOS V, ZYCHLINSKY A (2011). Myeloperoxidase is required for neutrophil extracellular trap formation: implications for innate immunity. Blood 117: 953-59.

MIKI T, HOLST O, HARDT W-D (2012). The bactericidal activity of the C-Type lectin Reglll $\beta$ against Gram-Negative bacteria involves binding to Lipid A. J Biol Chem 287: 34844-34855.

MOLMERET M, HORN M, WAGNER M (2005). Amoebae as training grounds for intracellular bacterial pathogens. Appl Environ Microbiol 71: 20-28.

MUKHERJEE S, ZHENG H, DEREBE M G, CALLENBERG K M, PARTCH C L, ROLLINS D, PROPHETER D C, RIZO J, GRABE M, JIANG Q X, HOOPER L $\checkmark$ (2014). Antibacterial membrane attack by a pore-forming intestinal C-Type Lectin. Nature 505: 103-7.

NAKAMURA K, SAKURAGI N, TAKAKUWA A, AYABE T (2016). Paneth cell $\alpha$ defensins and enteric microbiota in health and disease. Bioscience Microbiota Food Health 35: 57-67.

NASSER W, SANTHANAM B, MIRANDAR, PARIKHA, JUNEJAK, ROT G, DINH C, CHEN R, ZUPAN B, SHAULSKY G, KUSPA A (2013). Bacterial discrimination by Dictyostelid amoebae reveals the complexity of ancient interspecies interactions. Curr Biol 23: 862-872.

NISHIDAA, INOUE R, INATOMI O, BAMBAS, NAITOY, ANDOH A (2018). Gut Microbiota in the Pathogenesis of Inflammatory Bowel Disease. Clin J Gastro 11: 1-10.

OFEK I, SHARON N (1988). Lectinophagocytosis: a molecular mechanism of recognition between cell surface sugars and lectins in the phagocytosis of bacteria. Infect Immun 56: 539-547.

OFEK I, GOLDHAR J, KEISARI Y, SHARON N (1995). Nonopsonic phagocytosis of microorganisms. Annu Rev Microbiol 49: 239-276.

OUELLETTE AJ (2010). Paneth Cells and Innate Mucosal Immunity. Curr Op Gastro 26: $547-553$.

PALIĆ D, OSTOJIĆ J, ANDREASEN C B, ROTH J A (2007). Fish cast NETs: neutrophil extracellular traps are released from fish neutrophils. Develop Comp Immunol 31: 805-816.

PAPAYANNOPOULOS $V$ (2018). Neutrophil extracellular traps in immunity and disease. Nat Rev. Immunol 18: 134-47.

PAPAYANNOPOULOS V, METZLER K D, HAKKIM A, ZYCHLINSKY A (2010). Neutrophil elastase and myeloperoxidase regulate the formation of neutrophil extracellular traps. J Cell Biol 191: 677-691.

PAQUET VE, CHARETTE SJ (2016). Amoeba-resisting bacteria found in multilamellar bodies secreted by Dictyostelium discoideum: social amoebae can also package bacteria. FEMS Microbiol. Ecol. 92 (3). doi:10.1093/femsec/fiw025

PETERSON L W, ARTIS D (2014). Intestinal epithelial cells: regulators of barrier function and immune homeostasis. Nat Rev Immunol 14: 141-153.

PORTER E M, BEVINS C L, GHOSH D, GANZ T (2002). The multifaceted paneth cell. Cell and Mol Life Sci 59: 156-70.

ROBERGE-WHITE E, KATOH-KURASAWA M (2011). Plasticity in the development and dedifferentiation of Dictyostelium discoideum. Dev. Growth Differ53:587-596.
ROSENGARTEN R D, SANTHANAM B, FULLER D, KATOH-KURASAWA M, LOOMIS W F, ZUPAN B, SHAULSKY G (2015). Leaps and lulls in the developmental transcriptome of Dictyostelium discoideum. BMC Genomics 16: 1-16.

ROWEKAMP W, POOLE S, FIRTEL R A (1980). Analysis of the Multigene Family Coding the Developmentally Regulated Carbohydrate-Binding Protein Discoidin-I in D. Discoideum. Cell 20: 495-505.

RUBIN M, MILLERAD, DINH C, KUSPAA, SHAULSKY G (2019). Cooperative predation in the social amoebae Dictyostelium discoideum. PLoS One, 14: e0209438. doi: 10.1371/journal.pone.0209438.

SALZMAN N H, HUNG K, HARIBHAI D, CHU H, KARLSSON-SJOBERG J, AMIR E, TEGGATZ P, BARMAN M, HAYWARD M, EASTWOOD D, STOEL M, ZHOU Y, SODERGREN E, WEINSTOCK G M, BEVINS C L, WILLIAMS C B, BOS N A (2010). Enteric Defensins Are Essential Regulators of Intestinal Microbial Ecology. Nature Immunol 11: 76-82.

SESAKI H, WONG E F S, SIU C-H (1997). The Cell Adhesion Molecule DdCAD-1 in Dictyostelium Is Targeted to the Cell Surface by a Nonclassical Transport Pathway Involving Contractile Vacuoles. J Cell Biol 138: 939-51.

SHIU J, GASPARI A A (2017). Toll-like Receptors. Clin Basic Immunodermatol 21 : 11-34.

SHU L, BROCK D A, GEIST K S, MILLER J W, QUELLER D C, STRASSMANN J E, DISALVO S (2018). Symbiont location, host fitness, and possible coadaptation in a symbiosis between social amoebae and bacteria. eLife 7. doi:10.7554/eLife.42660

SINAC, KEMPER C, DERERS (2018). The intestinal complement system in inflammatory bowel disease: Shaping Intestinal Barrier Function. Sem Immuno/37: 66-73.

Singh R K, CHANG H W, YAN D, LEE K M, UCMAK D, WONG K, ABROUK M, FARAHNIK B, NAKAMURA M, ZHU TH, BHUTANI T, LIAO W (2017). Influence of Diet on the Gut Microbiome and Implications for Human Health. J Trans/Med 15: 1-17.

SRISKANTHADEVAN S, LEE T, LIN Z, YANG D, SIU C-H (2009). Cell adhesion molecule DdCAD-1 is imported into contractile vacuoles by membrane invagination in a Ca2+- and conformation-dependent manner. J Biol Chem 284: 36377-36386.

SRISKANTHADEVAN S, ZHUY, MANOHARAN K, YANG D, SIU C-H (2011). The cell adhesion molecule DdCAD-1 regulates morphogenesis through differential spatiotemporal expression in Dictyostelium discoideum. Development 138: 2487-2497.

SRISKANTHADEVAN, S, BRAR SK, MANOHARAN K, SIU C-H. (2013). Ca(2+)calmodulin Interacts with DdCAD-1 and promotes DdCAD-1 transport by contractile vacuoles in Dictyostelium cells. FEBS J 280: 1795-1806.

STALLFORTH P, BROCK D A, CANTLEY A M, TIAN X., QUELLER D C, STRASSMANN J E, CLARDY J (2013). A Bacterial Symbiont Is Converted from an Inedible Producer of Beneficial Molecules into Food by a Single Mutation in the GacA Gene. Proc Natl Acad Sci USA 110: 14528-14533.

STRMECKI L, BLOOMFIELD G, ARAKI T, DALTON E, SKELTON J, SCHILDE C, HARWOOD A, WILLIAMS J G, IVENS A, PEARS C (2007). Proteomic and Microarray Analyses of the Dictyostelium Zak1-GSK-3 Signaling Pathway Reveal a Role in Early Development. Euk Cell 6: 245-52.

STRUGALA V, DETTMAR, P W, PEARSON J P (2008). Thickness and Continuity of the Adherent Colonic Mucus Barrier in Active and Quiescent Ulcerative Colitis and Crohn's Disease. Intl J Clin Prac 62: 762-769.

SWIDSINSKIA, WEBER J, LOENING-BAUCKE V, HALELP, LOCHSH(2005). Spatial Organization and Composition of the Mucosal Flora in Patients with Inflammatory Bowel Disease Spatial Organization and Composition of the Mucosal Flora in Patients with Inflammatory Bowel Disease. J Clin Microbiol 43: 3380-3389.

SZYKA, WUZ, TUCKERK, YANG D, LUW, LUBKOWSKI J (2006). Crystal Structures of Human Alpha-Defensins HNP4, HD5, and HD6. Protein Sci 15: 2749-2760.

VAISHNAVA S, YAMAMOTO M, SEVERSON K M, RUHN KA, YU X, KOREN O, LEY R, WAKELAND E K, HOOPER L V (2011). The Antibacterial Lectin Reglllgamma Promotes the Spatial Segregation of Microbiota and Host in the Intestine. Science 334: 255-258.

VARGAS P, BARBIER L, SÁEZ P J, PIEL M (2017). Mechanisms for fast cell migration in complex environments. Curr Opin Cell Biol 48: 72-78.

VINOGRADOV E, FRIRDICHE, MACLEAN LL, PERRY MB, PETERSENB O, DUUS J O, WHITFIELD C (2002). Structures of lipopolysaccharides from Klebsiella pneumoniae. Eluicidation of the structure of the linkage region between core and polysaccharide $O$ chain and identification of the residues at the non-reducing termini of the $O$ chains. $J$ Biol Chem 277: 25070-25081.

WALSH U F, MORRISSEY J P, O'GARA F (2001). Pseudomonas for biocontrol of phytopathogens: from functional genomics to commercial exploitation. Curr $\mathrm{Op}$ 
Biotech 12: 289-295.

WEHKAMP J, STANGE E F (2010). Paneth's Disease. J Crohn Colitis 4: 523-531.

WONG E F S, BRAR S K, SESAKI H, YANG C Z, SIU C-H (1996). Molecular Cloning and characterization of DdCAD-1, a Ca2+-dependent cell-cell adhesion molecule, in Dictyostelium discoideum. J Biol Chem 271: 16399-16408.

WONG E, YANG C, WANG J, FULLER D, LOOMIS W F, SIU C-H (2002). Disruption of the gene encoding the cell adhesion molecule DdCAD-1 leads to aberrant cell sorting and cell-type proportioning during Dictyostelium development. Development 129: 3839-3850.

XIA X, YOU M, RAO X J, YU X Q (2018). Insect C-Type lectins in innate immunity. Dev Comp Immun. 83: 70-79.

YOUSEFI S, GOLD J A, ANDINA N, LEE J J, KELLY AM, KOZLOWSKI E, SCHMID I, STRAUMANNA, REICHENBACH J, GLEICH G J, SIMONHU (2008). Catapult-like release of mitochondrial DNA by eosinophils contributes to antibacterial defense. Nat Med 14: 949-953.

YOUSEFI S, MIHALACHE C, KOZLOWSKI E, SCHMID I, SIMON HU (2009). Viable neutrophils release mitochondrial DNA to form neutrophil extracellular traps. Cell Death Dif 16: 1438-1444.

YOUSEFI S, SIMON D, SIMON H U (2012). Eosinophil extracellular DNA traps: molecular mechanisms and potential roles in disease. Curr Opin Immunol24:736-739

ZELENSKY A N, GREADY J E (2005). The C-Type lectin-like domain superfamily. FEBS J 272: 6179-6217.

ZHANG X, SOLDATI T (2016). Of amoebae and men: extracellular DNA traps as an ancient cell-intrinsic defense mechanism. Front Immunol 7: 269-273.

ZHANG X, ZHUCHENKO O, KUSPA A, SOLDATI T (2016). Social Amoebae Trap and Kill Bacteria by Casting DNA Nets. Nat Commun 7: 1-9. 
Further Related Reading, published previously in the Int. J. Dev. Biol.

Evidence for an evolutionary relationship between Vmp1 and bacterial DedA proteins Luis-Carlos Tábara, Olivier Vincent and Ricardo Escalante

Int. J. Dev. Biol. (2019) 63: 67-71

https://doi.org/10.1387/ijdb.180312re

Dictyostelium discoideum Sir2D modulates cell-type specific gene expression and is involved in autophagy

Rakhee Lohia, Punita Jain, Mukul Jain, Pradeep Kumar Burma, Anju Shrivastava and Shweta Saran

Int. J. Dev. Biol. (2017) 61: 95-104

https://doi.org/10.1387/ijdb.160038ss

ASET/MYND chromatin re-modelling protein regulates Dictyostelium prespore patterning Beatriz Nuñez-Corcuera, Joanna Birch and Jeffrey G. Williams

Int. J. Dev. Biol. (2011) 55: 205-208

https://doi.org/10.1387/ijdb.113309bn

Identification of a target for CudA, the transcription factor which directs formation of the Dictyostelium tip organiser

Hong-Yu Wang and Jeffrey G. Williams

Int. J. Dev. Biol. (2010) 54: 161-165

https://doi.org/10.1387/ijdb.082723hw

Cell cycle phase, cellular Ca2+ and development in Dictyostelium discoideum MAzhar, PKKennady, G Pande, M Espiritu, W Holloman, D Brazill, RH Gomer and V Nanjundiah Int. J. Dev. Biol. (2001) 45: 405-414

http://www.intjdevbiol.com/web/paper/11330860

Dictyostelium discoideum: a model system for differentiation and patterning

$R$ Escalante and $\mathrm{J} J$ Vicente

Int. J. Dev. Biol. (2000) 44: 819-835

http://www.intjdevbiol.com/web/paper/11206323

Cell-cell signaling and adhesion in phagocytosis and early development of Dictyostelium E Bracco, B Pergolizzi, B Peracino, E Ponte, A Balbo, A Mai, A Ceccarelli and S Bozzaro Int. J. Dev. Biol. (2000) 44: 733-742

http://www.intjdevbiol.com/web/paper/11061438
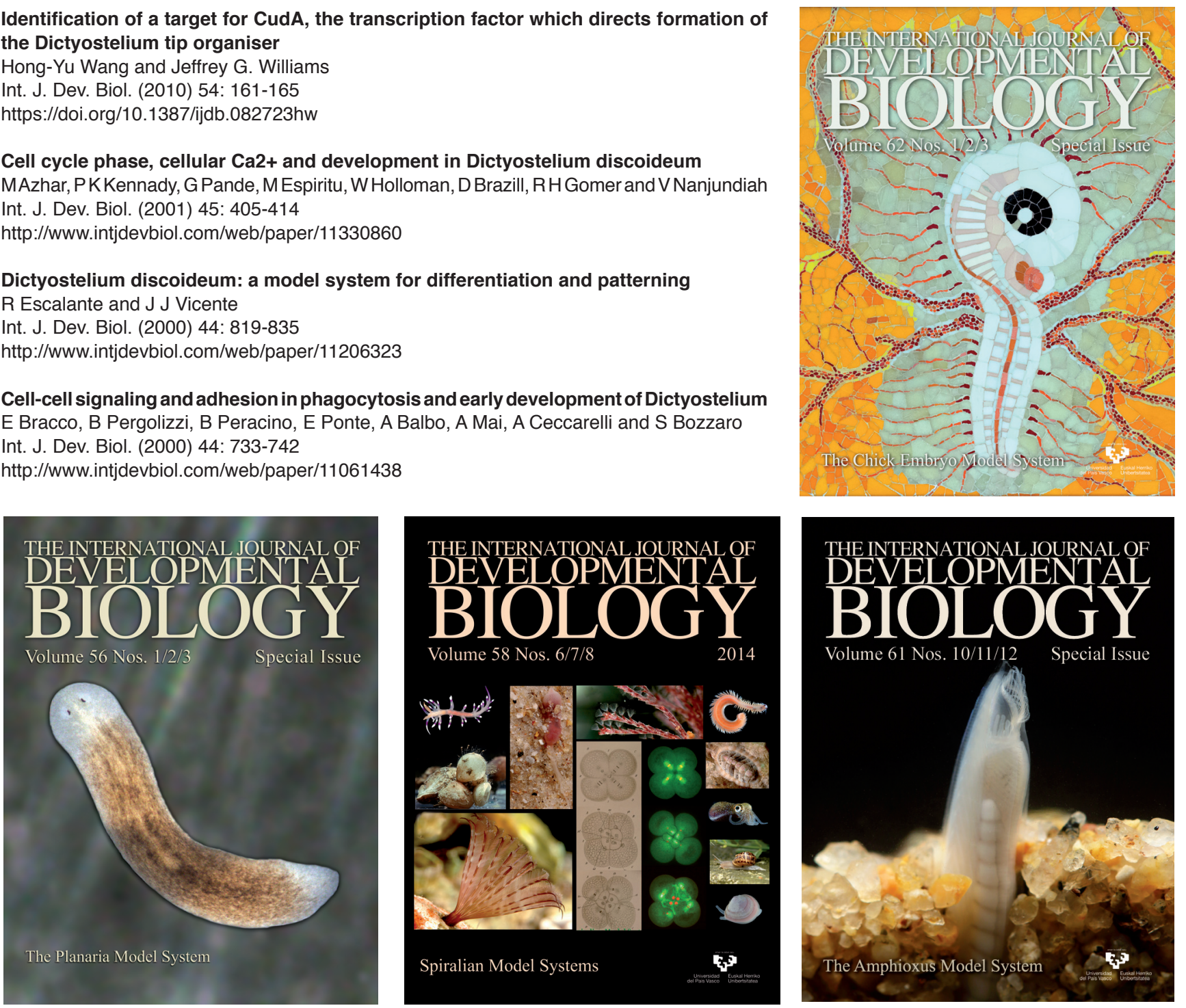